\title{
THE STATUS OF HAIR MINERALS IN CHRONIC FATIGUE AND DEPRESSED WOMEN
}

\author{
HWEE-SOO JEONG* \\ Department of Family Medicine and Integrative Medicine, College of Medicine, Dongguk University, Gyeongju, South Korea. \\ Email: hweesoo@dongguk.ac.kr
}

Received: 27 August 2018, Revised and Accepted: 10 October 2018

ABSTRACT

Objective: Chronic fatigue and depression are common problems in primary care. The status of micronutrients may be related to two conditions. The present study aimed to identify the association of minerals with chronic fatigue and depression.

Methods: We conducted a cross-sectional study using medical records of 97 female patients aged 20-64 years old who visited the integrated medical center of a university hospital in Gyeongju, South Korea, from 2013 to 2016 . Collected information comprised their scores for the fatigue severity scale, beck depression inventory, and concentrations of mineral in hair samples.

Results: The subjects were classified into three groups according to their depression and fatigue scores: 21 patients (21.6\%) were free of fatigue and depression, 55 (56.8\%)experienced fatigue without depression, and 21 (21.6\%) experienced fatigue with depression. The potassium (K) concentration in hair significantly decreased in the groups of fatigue or fatigue with depression compared to the group with free of fatigue and depression $(\mathrm{p}=0.042)$. The trend of sodium $(\mathrm{Na}), \mathrm{K}$ concentration, and $\mathrm{Na} /$ magnesium $(\mathrm{Mg})$ ratios in hair gradually decreased with fatigue and depression ( $\mathrm{p}$ for trend $=0.027,0.037$, and 0.03 ).

Conclusion: Chronic fatigue and depression in women are associated with the concentrations of hair minerals, especially Na, $\mathrm{K}$, and $\mathrm{Na} / \mathrm{Mg}$ ratios.

Keywords: Fatigue, Depression, Sodium, Potassium, Hair.

(C) 2018 The Authors. Published by Innovare Academic Sciences Pvt Ltd. This is an open access article under the CC BY license (http://creativecommons. org/licenses/by/4. 0/) DOI: http://dx.doi.org/10.22159/ajpcr.2018.v11i11.29335

\section{INTRODUCTION}

Fatigue is a commonly seen symptom in primary care. The prevalence of chronic fatigue lasting more than 6 months is 30\%, and approximately half of these patients visit a primary care clinic [1]. Chronic fatigue is often caused by mood disorders and, therefore, the use of antidepressants and antianxiety medications is 3 times higher in patients with chronic fatigue as compared to the general population [2]. Furthermore, depression in patients presenting at primary care sites can appear similar to other medical conditions such as chronic pain, fatigue, or gastrointestinal disorders rather than as classic depressive symptoms [3]

Micronutrient deficiency is also considered to be a cause of fatigue. These are involved in cell metabolism, including mitochondrial function. Mitochondrial dysfunction is a cause of the chronic fatigue syndrome [4,5]. A lack of minerals related to oxidative stress, such as magnesium (Mg), is associated with chronic fatigue [6]. Depression is also affected by nutritional status. Depressive patients have low vitamin and minerals intake [7]. Therefore, this study aimed to identify the association of micronutrient such as minerals with chronic fatigue and depression.

\section{METHODS}

A retrospective cross-sectional study was performed using the medical records of chronic fatigue patients aged 20-64 years old who visited the integrated medical center of a university hospital in Gyeongju, South Korea, from June 2013 to August 2016. All fatigue patients who visited the integrated medical center had a medical interview were taken laboratory tests and completed the Korean versions $(\mathrm{K})$ of the fatigue severity scale (FSS) and the Beck depression inventory-K (BDI-K) questionnaire to assess their degree of fatigue and depression before treatment. We excluded cases with missing values in the questionnaires or cases that were diagnosed with tuberculosis, liver disease, anemia, thyroid disease, or depression with medication. Male patients were excluded from the study because there were fewer than 10 cases. Finally, 97 female patients were included in the study. The study plan was approved after review by the same hospital's Institutional Review Board (IRB Number: 110757-2017-10-HR-02-01).

The FSS is a self-reported questionnaire that consists of nine items about fatigue experienced during the past week to be rated on a 7-point scale [8]. The higher average score of the questionnaire, the more severe fatigue. In the $\mathrm{K}$ of the FSS, fatigue is considered to be present at a cutoff point of 3.22 or higher $[9,10]$. The BDI-K is the K of a screening tool for depression. 21 items are rated on a 4-point Likert-type scale according to symptom severity. The higher total score, the more severe depressive symptoms. In this study, 24 points were used as the cutoff point for depression [11,12].

Minerals were evaluated using hair samples. For hair tissue mineral analysis, approximately $150 \mathrm{mg}$ hair samples were obtained by cutting the $1^{\text {st }} 3 \mathrm{~cm}$ of hair closest to the scalp, at the nape of the neck. Before sampling, the dying and perming of hair were excluded for at least 4 weeks. The samples were sent to the US Trace Elements, Inc. (TEI, Dallas, TX, USA) through Korea TEI. In the US, after washing the hair samples with chemical agents (non-ionic surfactants, deionized water, and acetone) and acid decomposition with nitric acid, the digestive procedure using a high volume and uniform temperature controlled microwave oven (Mars 5 Plus, CEM Corp, NC, USA) was performed. Analysis was performed using inductively coupled plasma mass spectrometry (ICP-MS, a NexION 2000 ICP mass spectrometer, Perkin Elmer Corp., Foster City, CA, USA). Mineral concentrations are reported as $\mu \mathrm{g} / \mathrm{g}$. Data for calcium $(\mathrm{Ca}), \mathrm{Mg}$, sodium $(\mathrm{Na})$, potassium $(\mathrm{K})$, copper $(\mathrm{Cu})$, zinc $(\mathrm{Zn})$, phosphate $(\mathrm{P}), \mathrm{Ca} / \mathrm{P}$, $\mathrm{Na} / \mathrm{K}, \mathrm{Ca} / \mathrm{K}, \mathrm{Zn} / \mathrm{Cu}, \mathrm{Na} / \mathrm{Mg}$, and $\mathrm{Ca} / \mathrm{Mg}$ were obtained $[13,14]$.

The mean \pm standard deviation of the questionnaire scores for all subjects was calculated. All subjects were classified as fatigued or not and depressed or not using the cutoff points described above. Although some of the groups were small in terms of their sample size, parametric 
statistics were used for adjusting age. Adjusted for age, partial correlation analysis was performed between concentrations of hair mineral and the score of FSS or BDI-K. The subjects were divided into three groups: Fatigue and depression free, fatigue without depression, and fatigue with depression. A general linear model adjusted for age was used to compare the differences in hair mineral density among these three groups. In addition, linear contrast analysis was used to analyze trends in mineral concentration among the three groups. Statistical analysis was performed using Statistics is a Software Package Version 20.0 Inc., TX, USA. Statistical significance was set at $\mathrm{p}<0.05$.

\section{RESULTS}

The mean age of the subjects was $48.59 \pm 9.64$ years (range: $20-64$ years). The mean FSS score for all subjects was $4.39 \pm 1.55$ (range: 1.0-7.67) and the mean BDI-K score was $16.12 \pm 9.86(0-41)$. According to these scores, $76(78.4 \%)$ of the 97 patients were fatigued and $21(21.6 \%)$ were depressed. All depressed patients included the group of fatigue. When the subjects were classified into three groups according to fatigue and depression, 21 patients $(21.6 \%)$ were free of both fatigue and depression, $55(56.7 \%)$ had fatigue without depression, and $21(21.6 \%)$ had fatigue with depression.

Table 1 shows negative correlations between the concentrations of hair $\mathrm{Na}, \mathrm{K}$, and the score of FSS. The $\mathrm{Na} / \mathrm{Mg}$ ratio was also negatively

Table 1: Partial correlation coefficients between hair minerals and scores of FSS and BDI-K in all subjects ( $n=97)$

\begin{tabular}{|c|c|c|}
\hline \multirow[t]{2}{*}{ Hair minerals } & FSS scores & BDI-K scores \\
\hline & $\mathbf{R}$ & $\mathbf{R}$ \\
\hline $\mathrm{Ca}(\mu \mathrm{g} / \mathrm{g})$ & 0.000 & 0.108 \\
\hline $\mathrm{Ma}(\mu \mathrm{g} / \mathrm{g})$ & -0.014 & 0.043 \\
\hline $\mathrm{Na}(\mu \mathrm{g} / \mathrm{g})$ & $-0.217^{*}$ & -0.088 \\
\hline $\mathrm{K}(\mu \mathrm{g} / \mathrm{g})$ & $-0.266^{*}$ & 0.006 \\
\hline $\mathrm{Cu}(\mu \mathrm{g} / \mathrm{g})$ & -0.054 & -0.054 \\
\hline $\mathrm{Zn}(\mu \mathrm{g} / \mathrm{g})$ & -0.019 & -0.019 \\
\hline $\mathrm{P}(\mu \mathrm{g} / \mathrm{g})$ & -0.115 & -0.115 \\
\hline $\mathrm{Ca} / \mathrm{P}$ & 0.048 & 0.118 \\
\hline $\mathrm{Na} / \mathrm{K}$ & -0.021 & -0.076 \\
\hline $\mathrm{Ca} / \mathrm{K}$ & 0.056 & 0.092 \\
\hline $\mathrm{Zn} / \mathrm{Cu}$ & -0.013 & 0.026 \\
\hline $\mathrm{Na} / \mathrm{Mg}$ & $-0.216^{*}$ & -0.073 \\
\hline $\mathrm{Ca} / \mathrm{Mg}$ & 0.021 & 0.071 \\
\hline
\end{tabular}

Data expressed as partial correlation coefficient (r). *Significant values, $\mathrm{p}<0.05$, using partial correlation analysis adjusted by age. FSS: Fatigue severity scale, BDI-K: Beck depression inventory-Korean version, Calcium (Ca), Magnesium (Mg), Sodium (Na), Potassium (K), Copper (Cu), Zinc (Zn),

Phosphate (P) correlated with the score of FSS. Other hair minerals correlated with the score of FSS. None of hair minerals correlated with the score of BDI-K.

The results of the comparison of the hair mineral content among the three groups showed that the $\mathrm{Na}, \mathrm{K}$ concentrations, and $\mathrm{Na} / \mathrm{Mg}$ ratios tended to be decreased with fatigue and depression. The hair $\mathrm{K}$ concentrations were significantly different $10.86 \pm 17.12 \mu \mathrm{g} / \mathrm{g}$ in the fatigue and depression-free group, $5.02 \pm 4.59 \mu \mathrm{g} / \mathrm{g}$ in the group of fatigue without depression, and $5.05 \pm 4.44 \mu \mathrm{g} / \mathrm{g}$ in the fatigue with depression group and tended to decrease with increasing fatigue and depression scores ( $p$ for trend 0.037). The Na concentration in hair was not significantly different among the three groups $(18.07 \pm 29.76 \mu \mathrm{g} / \mathrm{g}$, $11.74 \pm 11.56 \mu \mathrm{g} / \mathrm{g}$, and $8.32 \pm 6.37 \mu \mathrm{g} / \mathrm{g}$ for the fatigue and depression free, fatigue without depression, and fatigue with depression groups, respectively; $\mathrm{p}=0.06$ ) but showed a decreasing trend with increasing fatigue and depression scores ( $p=0.027$ for trend). The $\mathrm{Na} / \mathrm{Mg}$ ratios also tended to decrease with fatigue and depression at $4.93 \pm 10.71 \mu \mathrm{g} / \mathrm{g}, 1.96 \pm 3.20 \mu \mathrm{g} / \mathrm{g}$, and $1.15 \pm 1.78 \mu \mathrm{g} / \mathrm{g}$ in the three groups $(p=0.063$ and $p=0.03$ for trend). The concentrations of $\mathrm{Ca}$, $\mathrm{Mg}, \mathrm{Cu}, \mathrm{Zn}$, and $\mathrm{P}$ in hair showed no association with fatigue and depression (Table 2).

\section{DISCUSSION}

About $70 \%$ of the general population believes that vitamin and mineral supplementation can help to maintain health, and some studies have reported that supplementation improves subjective stress, mild psychiatric symptoms, anxiety, and fatigue $[15,16]$.

In this study, we found that the concentrations of $\mathrm{Na}$ and $\mathrm{K}$ in hair may be affected by fatigued and depressed women. The hair concentrations of $\mathrm{Na}$ and $\mathrm{K}$ tended to decrease with fatigue and depression. $\mathrm{Na}$ and $\mathrm{K}$ are important minerals involved in cell metabolism and blood pressure. The concentration of $\mathrm{Na}$ in tissue, not blood decreased in psychological stress [17]. Increased sympathetic response by stress also leads to neural mediated hypotension as a cause of lightheadedness and chronic fatigue [18]. Both low $\mathrm{Na}$ concentrations in tissue and hypotension increase serum aldosterone level, which increased $\mathrm{Na}$ reabsorption in kidney and urinary $\mathrm{K}$ excretion. A deficiency of $\mathrm{Na}$ affects mood and depression in animal study, and low dietary salt intake is associated with depression in women $[19,20]$

The relationship between the concentration of $\mathrm{K}$ in tissue and fatigue was also reported to have an inverse pattern [17]. A decrease in hair K concentration is caused by hyperaldosteronism [21]. Serum aldosterone level increases in the patients with early stage of depression but decreases in severe depression $[22,23]$. Decreased serum aldosterone

Table 2: Comparison of hair mineral concentrations among three patient groups with and without fatigue and depression

\begin{tabular}{|c|c|c|c|c|c|}
\hline \multirow[t]{2}{*}{ Hair minerals } & \multirow{2}{*}{$\begin{array}{l}\text { Fatigue }(-) \text { depression }(-) \\
n=21\end{array}$} & \multirow{2}{*}{$\begin{array}{l}\text { Fatigue (+) depression }(-) \\
n=55\end{array}$} & \multirow{2}{*}{$\begin{array}{l}\text { Fatigue }(+) \text { depression }(+) \\
n=21\end{array}$} & \multirow[t]{2}{*}{ p value } & \multirow[t]{2}{*}{$p$ for trend } \\
\hline & & & & & \\
\hline $\mathrm{Ca}(\mu \mathrm{g} / \mathrm{g})$ & $130.24 \pm 74.60$ & $124.55 \pm 78.62$ & $165.10 \pm 74.59$ & 0.139 & 0.145 \\
\hline $\mathrm{Na}(\mu \mathrm{g} / \mathrm{g})$ & $20.76 \pm 35.27$ & $11.11 \pm 10.82$ & $8.00 \pm 6.34$ & 0.060 & 0.027 \\
\hline $\mathrm{K}(\mu \mathrm{g} / \mathrm{g})$ & $10.86 \pm 17.12$ & $5.02 \pm 4.59$ & $5.05 \pm 4.44$ & 0.042 & 0.037 \\
\hline $\mathrm{Cu}(\mu \mathrm{g} / \mathrm{g})$ & $3.41 \pm 5.74$ & $2.86 \pm 4.21$ & $2.95 \pm 2.80$ & 0.895 & 0.734 \\
\hline $\mathrm{Zn}(\mu \mathrm{g} / \mathrm{g})$ & $19.81 \pm 9.99$ & $18.64 \pm 10.02$ & $18.43 \pm 6.38$ & 0.864 & 0.634 \\
\hline$P(\mu \mathrm{g} / \mathrm{g})$ & $15.67 \pm 2.61$ & $14.42 \pm 2.28$ & $14.90 \pm 4.97$ & 0.241 & 0.384 \\
\hline $\mathrm{Ca} / \mathrm{P}$ & $8.37 \pm 4.88$ & $8.60 \pm 5.15$ & $11.46 \pm 5.38$ & 0.089 & 0.055 \\
\hline $\mathrm{Na} / \mathrm{K}$ & $3.07 \pm 4.25$ & $3.59 \pm 6.93$ & $2.45 \pm 1.89$ & 0.779 & 0.723 \\
\hline $\mathrm{Ca} / \mathrm{K}$ & $44.62 \pm 49.86$ & $62.29 \pm 83.66$ & $81.57 \pm 86.30$ & 0.287 & 0.130 \\
\hline $\mathrm{Zn} / \mathrm{Cu}$ & $11.54 \pm 6.41$ & $11.30 \pm 7.93$ & $10.53 \pm 10.3$ & 0.925 & 0.691 \\
\hline $\mathrm{Na} / \mathrm{Mg}$ & $4.93 \pm 10.71$ & $1.96 \pm 3.20$ & $1.15 \pm 1.79$ & 0.063 & 0.030 \\
\hline $\mathrm{Ca} / \mathrm{Mg}$ & $14.94 \pm 3.94$ & $15.82 \pm 6.83$ & $15.61 \pm 4.49$ & 0.687 & 0.710 \\
\hline
\end{tabular}

Data expressed as mean \pm standard deviation. $\mathrm{p}$ value was calculated using a general linear model adjusted for age. $\mathrm{p}$ for trend was calculated by linear contrast analysis. Ca: Calcium, Mg: Magnesium, Na: Sodium, K: Potassium, Cu: Copper, Zn: Zinc, P: Phosphate 
causes a decrease in $\mathrm{Na}$ concentration in the body and reduces $\mathrm{K}$ excretion into the kidney.

$\mathrm{Mg}$ is the intracellular cation, a necessary cofactor of many enzymes and regulates the $\mathrm{Na}, \mathrm{K}$, and $\mathrm{Cl}$ cotransport systems [24]. Stress stimulates the adrenal gland to increase cortisol secretion. The increase in cortisol may facilitate cell metabolism, induce hypomagnesemia in the body, causing a decrease of cortisol secretion in the absence of adequate $\mathrm{Mg}$ supplements [25,26]. If chronic stress persists, this vicious cycle may result in functional insufficiency of the adrenal gland. In chronic stress or depression, the tissue concentration of cortisol decreases [27,28]. Hair Mg was inversely correlated with tissue cortisol level [29]. Therefore, the accumulation of $\mathrm{Mg}$ in tissues including hair may associate with the decline of cortisol. In this study, the hair Mg concentration increased with fatigue and depression, but this increasing tendency was not significant.

In summary, the hair minerals identified in the present study are thought to be associated with hormones of the adrenal gland, and further studies needed to confirm the mechanism of the association adrenal gland with chronic fatigue and depression. In addition, taking herbs such as Passiflora foetida, Bacopa monnieri, Dioscorea oppositifolia, or Alternanthera sessilis which are rich in $\mathrm{Na}$ and $\mathrm{K}$ can be considered to be an alternative treatment to improve the symptoms of chronic fatigue or depression $[30,31]$.

There are several limitations to this study. First, the mineral state of hair may not reflect that of the whole body and individual information of dietary intake is not reflected in this study. Second, generalization of the results is limited because this was a single-center study and subjects were only the Korean women. Finally, causality cannot be explained by a cross-sectional study design. Nevertheless, the results of this study are meaningful in that fatigue is commonly observed problems in primary care.

\section{CONCLUSION}

Chronic fatigue and depression in women affect the concentrations of minerals in the hair, especially $\mathrm{Na}$ and $\mathrm{K}$. As fatigue and depression progress, the hair $\mathrm{Na}$ and $\mathrm{K}$ concentrations tend to decrease.

\section{ACKNOWLEDGMENTS}

This study was supported by the Dongguk University Research Fund by 2014 .

\section{AUTHORS' CONTRIBUTION}

Jeong HS contributed to all the work of this article (conceived of this study, collected and analyzed the data, and drafted the manuscript).

\section{CONFLICTS OF INTEREST}

The author declares that they have no conflicts of interest.

\section{REFERENCES}

1. van't Leven M, Zielhuis GA, van der Meer JW, Verbeek AL, Bleijenberg G. Fatigue and chronic fatigue syndrome-like complaints in the general population. Eur J Public Health 2010;20:251-7.

2. Manu P, Matthews DA, Lane TJ. The mental health of patients with a chief complaint of chronic fatigue. A prospective evaluation and follow-up. Arch Intern Med 1988;148:2213-7.

3. De Wester JN. Recognizing and treating the patient with somatic manifestations of depression. J Fam Pract 1996;43 Suppl 6:3-15.

4. Vormann J. Magnesium: Nutrition and metabolism. Mol Aspects Med 2003;24:27-37.

5. Myhill S, Booth NE, McLaren-Howard J. Targeting mitochondrial dysfunction in the treatment of myalgic encephalomyelitis/chronic fatigue syndrome (me/cfs)-a clinical audit. Int J Clin Exp Med 2013;6:1-15.

6. Manuel y Keenoy B, Moorkens G, Vertommen J, Noe M, Nève
$\mathrm{J}$, De Leeuw I, et al. Magnesium status and parameters of the oxidant-antioxidant balance in patients with chronic fatigue: Effects of supplementation with magnesium. J Am Coll Nutr 2000;19:374-82.

7. Kaner G, Soylu M, Yüksel N, Inanç N, Ongan D, Başmısırlı E, et al. Evaluation of nutritional status of patients with depression. Biomed Res Int 2015;2015:521481.

8. Krupp LB, LaRocca NG, Muir-Nash J, Steinberg AD. The fatigue severity scale. Application to patients with multiple sclerosis and systemic lupus erythematosus. Arch Neurol 1989;46:1121-3.

9. Kim S, Bae WK, Kim JY, Jang M, Kim JH, Noh HH, et al. Validation of the Korean version of schedule of fatigue and anergia: General physician questionnaire. J Korean Med Sci 2016;31:159-63.

10. Chung KI, Song CH. Clinical usefulness of fatigue severity scale for patients with fatigue, and anxiety or depression. Korean J Psychosom Med 2001;9:164-73.

11. Lee EJ, Kim JB, Shin IH, Lim KH, Lee SH, Cho GA, et al. Current use of depression rating scales in mental health setting. Psychiatry Investig 2010;7:170-6.

12. Lee MK, Lee YH, Park SH, Sohn CH, Jung YJ, Hong SK, et al. A standardization study of beck depression inventory (I): Korean version (K-BDI): Reliability land factor analysis. Korean J Psychopathol 1995;4:77-95.

13. Trace Elements, Inc. Quality Assurance/Quality Control (QA/QC), Texas; 2018. Available from: http://www.traceelements.com/ LabServices/QualityAssurance.aspx.

14. Hong SR, Lee SM, Lim NR, Chung HW, Ahn HS. Association between hair mineral and age, BMI and nutrient intakes among Korean female adults. Nutr Res Pract 2009;3:212-9.

15. Sekhri K, Kaur K. Public knowledge, use and attitude toward multivitamin supplementation: A cross-sectional study among general public. Int J Appl Basic Med Res 2014;4:77-80.

16. Long SJ, Benton D. Effects of vitamin and mineral supplementation on stress, mild psychiatric symptoms, and mood in nonclinical samples: A meta-analysis. Psychosom Med 2013;75:144-53

17. Burton RF, Hinton JW, Neilson E, Beastall G. Concentrations of sodium, potassium and cortisol in saliva, and self-reported chronic work stress factors. Biol Psychol 1996;42:425-38.

18. Rowe PC, Bou-Holaigah I, Kan JS, Calkins H. Is neurally mediated hypotension an unrecognised cause of chronic fatigue? Lancet 1995;345:623-4.

19. Grippo AJ, Moffitt JA, Beltz TG, Johnson AK. Reduced hedonic behavior and altered cardiovascular function induced by mild sodium depletion in rats. Behav Neurosci 2006;120:1133-43.

20. Goldstein P, Leshem M. Dietary sodium, added salt, and serum sodium associations with growth and depression in the U.S. general population. Appetite 2014;79:83-90

21. Prejbisz A, Warchoł-Celińska E, Lenders JW, Januszewicz A. Cardiovascular risk in primary hyperaldosteronism. Horm Metab Res 2015;47:973-80.

22. Murck H, Held K, Ziegenbein M, Künzel H, Koch K, Steiger A. The renin-angiotensin-aldosterone system in patients with depression compared to controls--a sleep endocrine study. BMC Psychiatry 2003;3:15.

23. Hallberg L, Westrin A, Isaksson A, Janelidze S, Träskman-Bendz L, Brundin L. Decreased aldosterone in the plasma of suicide attempters with major depressive disorder. Psychiatry Res 2010;187:135-9.

24. Flatman PW. Mechanism of magnesium transport. Annu Rev Physiol 1991:53:259-71.

25. Kurajoh M, Ohsugi K, Kakutani-Hatayama M, Shoji T, Koyama H. Hypokalemia associated with pseudo-Cushing's syndrome and magnesium deficiency induced by chronic alcohol abuse. CEN Case Rep 2018;7:148-52.

26. Cinar V, Mogulkoc R, Baltaci AK, Polat Y. Adrenocorticotropic hormone and cortisol levels in athletes and sedentary subjects at rest and exhaustion: Effects of magnesium supplementation. Biol Trace Elem Res 2008;121:215-20.

27. Rimes KA, Papadopoulos AS, Cleare AJ, Chalder T. Cortisol output in adolescents with chronic fatigue syndrome: Pilot study on the comparison with healthy adolescents and change after cognitive behavioural guided self-help treatment. J Psychosom Res 2014;77:409-14.

28. Grynderup MB, Kolstad HA, Mikkelsen S, Andersen JH, Bonde JP, Buttenschøn HN, et al. A two-year follow-up study of salivary cortisol concentration and the risk of depression. Psychoneuroendocrinology 2013;38:2042-50.

29. Vanaelst B, Michels N, Huybrechts I, Clays E, Flórez MR, Balcaen L, et al. Cross-sectional relationship between chronic stress and mineral 
concentrations in hair of elementary school girls. Biol Trace Elem Res 2013;153:41-9.

30. Gogoi P, Kalita J.C. Mineral content of some edible medicinally important leafy vegetables of Kamrup district of Assam, India. Int J
Pharm Pharm Sci 2014;6:404-6.

31. Prashanth Kumar GM, Chikkapaih L, Nagayya S. Nutritional analysis of edible wild plants used by Hakki Pikki tribes of Hassan district, Karnataka, India. Int J Pharm Pharm Sci 2016;8:390-3. 